\title{
INTERNATIONAL OVERVIEW ON WASTE TO BIOFUEL OPTIONS WITH A FOCUS ON WASTE POTENTIALS IN GERMANY AND FUNDING INCENTIVES IN THE EC
}

\author{
J. KRETZSCHMAR ${ }^{1, *}$ \\ S. MAJER ${ }^{2}$ \\ M. KROEGER ${ }^{3}$
}

\author{
DBFZ Deutsches Biomasseforschungszentrum gemeinnützige $\mathrm{GmbH}$ \\ ${ }^{1}$ Biochemical Conversion Department \\ ${ }^{2}$ Bioenergy Systems Department \\ ${ }^{3}$ Department Biorefineries \\ Torgauer Straße 116, D-04347, Germany
}

Received: 02/12/11

Accepted: 09/03/12 *to whom all correspondence should be addressed: e-mail: : joerg.kretzschmar@dbfz.de

\begin{abstract}
Biofuels represent a possibility to reduce greenhouse gas (GHG) emissions within the transport sector. In this context the sustainability of biofuels, especially so called $1^{\text {st }}$ generation biofuels led to controversial discussions in the past. Biofuels from waste and residues represent a well suited but quantitative limited alternative due to their sustainability. At an international level, different approaches for converting waste and residues into biofuels can be found. Developing countries in general use classic transesterification of waste fats to produce biodiesel. Technically advanced options such as pyrolysis, gasification, Fischer-Tropsch-Diesel, anaerobic fermentation and distillation, as well as biogas production coupled with biomethane upgrading, are mostly found in industrialized countries. Within this study, different waste to biofuel options are reviewed ranging from small scale to industrial scale and take into account used raw materials, technological application and (potential) GHG-reduction. Further the potential of several wastes and residues for gasification processes and synthesis of biofuels in Germany is described. Biofuel from waste offers promising funding incentives because of the "double counting" according to 2009/28/EC and the switch in mandatory blending from an amount based quota to a GHG-based blending quota in 2015.
\end{abstract}

KEYWORDS: sustainability, land use, food production, biodiversity, waste, residues, thermochemical conversion, potential, funding.

\section{INTRODUCTION}

The Directive 2009/30/EC prescribes the reduction of life cycle GHG-emissions per energy unit of transport fuel up to $10 \%$ from 2020, based on the standard fuel emissions of 2010 (Article 7a). If this reduction is to be achieved through the use of biofuels, a saving of at least $35 \%$ of the GHG-

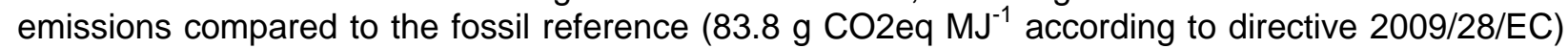
must be achieved. If not, the use of biofuels could not count towards the mandatory blending quota. From the start of 2016, the GHG-reduction to be achieved by the production of bioefuels has been set to $50 \%$ with and increase to $60 \%$ in the event that production starts after 1st, 2017 (Article $7 \mathrm{~b}$ of the directive 2009/30/EC). Independent of existing directives which regulate the emissions reduction and promote the prevention of direct land use change (LUC), future biofuel production has to consider other relevant sustainability criteria. These include issues like indirect land use change (ILUC), biodiversity, land use in general, the competition with food production in particular, as well as criteria of social sustainability. Biofuels from waste and residues can fulfil these criteria, provided that international human rights and labour standards are considered. The aim of this study is to provide a short overview of the sustainability issues related to $1^{\text {st }}$ generation biofuels in combination with an assessment of different solution oriented approaches. This will also be followed by an outlook of existing waste to biofuel technologies, ranging from industrial to demonstration scale, as well as identifying their potential as a fuel. Therefore a project review on international level was done. The potential of wastes and residues for biofuels is limited, but should be considered due to their excellent GHG saving potential. Thermochemical conversion is one such promising technology, 
producing biofuels from woody and herbaceous waste and residues. The technical potential of different categories of waste and residues in Germany, suitable for thermochemical conversion, is shown in Table 3. Finally the study focuses on one possibility to fund the enhanced production and integration of biofuels from waste and residues. The sustainability advantages of biofuels from waste and residues are considered within the directive 2009/28/EC, in the form of a special funding incentive, the so called "double counting". This means the possibility to count them twice towards the mandatory blending quota, which gives them an economic advantage in comparison to other biofuels.

\section{SUSTAINABILITY OF $\mathbf{1}^{\text {st }}$ GENERATION BIOFUELS}

Current biofuels are based on agricultural products like oil or sugar bearing plants. Most of the GHG emissions associated with the use of $1^{\text {st }}$ generation biofuels accrue from biomass cultivation and land use change. Nitrous oxide $\left(\mathrm{N}_{2} \mathrm{O}\right)$ has the highest climate damaging potential per weight and originates from nitrogen fertilizer treated soils. One ton of nitrous oxide has a 296 times stronger effect than Carbon dioxide (2009/28/EC) and $65 \%$ of the worldwide $\mathrm{N}_{2} \mathrm{O}$ emissions result from agriculture (Meissner, 2009).

\section{Direct and indirect land use change}

The increasing production of food, fodder and biofuels in the past resulted in direct (LUC) and indirect land use change (ILUC) and associated GHG emissions. Between 1980 and 2000 for example, $78 \%$ of new agricultural land in the tropical climate zone was established on former woodland (Gibbs et al., 2010). While LUC is already part of sustainability certification schemes for biofuel production, outlined in the EU-Directive 2009/28/EG, ILUC remains uncertain as of yet there is no clear calculation method. It is very difficult to prove that the displacement of former land use on areas with high carbon stock has been triggered by biofuel production. Therefore the hitherto evaluated ILUC GHG-emissions range between $30-103 \mathrm{~g} \mathrm{CO}_{2} \mathrm{eq} \mathrm{MJ}^{-1}$ biofuel (Fischer et al., 2009; Cornelissen Dehue, 2009). With such additional emissions the European GHG reduction objectives cannot be achieved.

\section{Impacts on biodiversity and competition for arable land}

Biomass production within intensive agriculture also has an impact on biodiversity. Biodiversity includes all spheres of life influenced by producers, consumers and reducers (Vohland Doyle Cramer, 2008). The stability of this cycle and all its associated processes is crucial for an everlasting function of environmental services occupied by humans. Enhanced cultivation of biomass for energy purposes as well as intensive food production can result in cultivation of monocultures, which is in contrast with the international convention on biological diversity. Regarding the food vs. fuel debate, the growing demand of food and fodder worldwide, particularly in developing and emerging countries, requires a worldwide increase in agricultural production of at least $50 \%$ to avoid an increase in food insecurity (WBGU, 2009). Additionally there is a worldwide development towards a more meat based nutrition, which is responsible a high demand in fodder for livestock farming. This demand actually accounts for the use of $69 \%$ of worldwide arable land (livestock keeping and fodder production) (FAOSTAT, 2010). A paradigm shift in eating habits towards a higher share of plant-based food could release a considerable amount of arable land for the production of vegetable food and simultaneously reduce GHG emissions from livestock keeping (Hirschfeld et al., 2008). The conflicting demand between food and fodder (for livestock) is exacerbated further by the scarcity of arable land and enhanced production of $1^{\text {st }}$ generation biofuels.

\section{The feasibility of biomass cultivation on degraded lands}

As mentioned, the production of biofuels competes with food and fodder production for arable land. To reduce the scarcity and competition for agricultural land, the energy crop cultivation on degraded and marginal lands (e.g. for biofuel production) is often a discussed approach to create new cultivation opportunities without affecting food and fodder production. Degraded lands are defined as areas formerly used for agricultural production, but faced with strongly decreasing productivity because of improper agricultural production or natural erosion. Land degradation represents a loss of ecosystem services that is not reversible under natural conditions (Wiegmann Hennenberg Fritzsche, 2008; UNEP, 2007). Marginal lands in comparison to degraded lands are characterized by low productivity, due to poor soil conditions. Besides degraded and marginal lands, there also exists an amount of abandoned farmland. Converting degraded or marginal lands back to productivity however requires huge investment (Balooni Singh, 2003). The area of degraded lands globally is 
estimated to be between $500-3500$ mill ha (Hoogwijk, 2004; Bai et al., 2008). According to Hoogwijk, 0-480 mill ha could be able to produce biomass (Hoogwijk, 2004). Worldwide abandoned farmland is specified with $385-472$ mill ha by Campbell et.al. (2008). Field et al. (2008) calculated 386 mill ha on the basis of satellite images, but this result includes a $50 \%$ margin of error (Field Campbell Lobell, 2007; Cotula Vermeulen Vermeulen 2008). Concerning the suitability of low productive areas for biomass production, the existing infrastructure and general transport distances must be taken into account. In general it is unclear when, where and in what quantities these abandoned or degredated areas could be utilised for biomass production.

Table 1. Selected types of waste and residues and hence producible biofuels.

Some of the technologies are still in development and some of the substrates require a previous conditioning e.g. enzymatic treatment, drying, ensiling, pyrolysis or torrefaction

\begin{tabular}{|c|c|}
\hline Wastel Residues & Biofuels \\
\hline \multicolumn{2}{|l|}{ Residues form agriculture } \\
\hline Straw & $\begin{array}{l}\text { Bio-SNG }{ }^{3,{ }^{*}}, \text { Methanol }^{3, *}, \text { Ethanol }^{2,3,{ }^{*}},{ }^{*} \text { FT-Diesel }{ }^{3, *}, \\
\text { Petrol }{ }^{3}, \text { DME }^{3,{ }^{*}}\end{array}$ \\
\hline Cereal husks & $\begin{array}{l}\text { Bio-SNG }{ }^{3, *}, \text { Methanol }^{3, *}, \text { Ethanol }^{2,3, *}, \text { FT-Diesel } l^{3, *}, \\
\text { Petrol }{ }^{3}, \text { DME }^{3, *}\end{array}$ \\
\hline Liquid manure & Biomethan $^{1}$ \\
\hline $\begin{array}{l}\text { Plant residues (e.g. coconut shells, empty palm } \\
\text { oil fruit bunches etc.) }\end{array}$ & $\begin{array}{l}\text { Bio-SNG }{ }^{3,{ }^{*}}, \text { Methanol }^{3,{ }^{*}}, \text { Ethanol }^{3,{ }^{*}}, \text { FT-Diesel }^{3,{ }^{*}}, \\
\text { Petrol }^{3}, \mathrm{DME}^{3,{ }^{*}}\end{array}$ \\
\hline \multicolumn{2}{|l|}{ Green waste } \\
\hline Grass clippings & Biomethan $^{1}$, Ethanol $^{2,3, *}$ \\
\hline Hay & 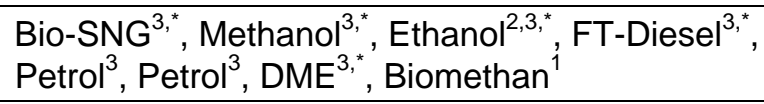 \\
\hline \multicolumn{2}{|l|}{ Woody residues } \\
\hline Untreated waste wood & $\begin{array}{l}\text { Bio-SNG }^{3}, \text { Methanol }^{3}, \text { Ethanol }^{3}, \text { FT-Diesel }^{3}, \\
\text { Petrol }^{3}, \text { DME }^{3}\end{array}$ \\
\hline Wood from landscape conservation & $\begin{array}{l}\text { Bio-SNG }^{3}, \text { Methanol }^{3}, \text { Ethanol }^{3}, \text { FT-Diesel }^{3}, \\
\text { Petrol }^{3}, \text { DME }^{3}\end{array}$ \\
\hline Sawing residues & $\begin{array}{l}\text { Bio-SNG }^{3}, \text { Methanol }^{3}, \text { Ethanol }^{3}, \text { FT-Diesel }^{3}, \\
\text { Petrol }^{3}, \text { DME }^{3}\end{array}$ \\
\hline Logging remains & $\begin{array}{l}\text { Bio-SNG }^{3}, \text { Methanol }^{3}, \text { Ethanol }^{3}, \text { FT-Diesel }^{3}, \\
\text { Petrol }^{3}, \text { DME }^{3}\end{array}$ \\
\hline \multicolumn{2}{|l|}{ Miscellaneous } \\
\hline Catering waste & Biomethan $^{1}$ \\
\hline Residues from food processing & Biomethan $^{1}$, Ethanol $^{2, *}$ \\
\hline Organic household waste (lignin low) & Biomethan $^{1}$ \\
\hline Dry organic waste & 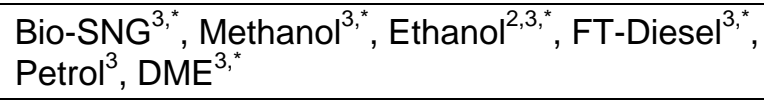 \\
\hline Waste fat or oil, animal fat & Biodiesel $^{4}$ \\
\hline $\begin{array}{l}\text { Slaughtering waste } \\
\text { (only categories } 2 \text { and } 3 \text { according to edict (EC) } \\
\text { nr. 1774/2002) }\end{array}$ & Biomethan $^{1}$ \\
\hline
\end{tabular}

The availability of land, whether it is arable or degraded land, also depends on prevailing land use rights. Especially in developing or emerging countries, where land rights are very often not regulated and informally managed. Here the land is used primarily for self-supply with food or (wood) fuel (Wiegmann Hennenberg Fritzsche, 2008). Within the context of the food vs. fuel debate and the scarcity of land, the biofuel related increase in food prices is an often discussed topic which cannot 
be reduced merely to the higher demand for commodities for biofuel production. The reasons for the dramatic price increase lie in the tremendous rise in demands for food and fodder, temporarily yield decreases (Zeddies, 2006) and low stocks. Other influential factors are the oil price, export and import strategies, increasing prices for fertilizer, protectionism of domestic markets and speculative investments (Jyväskylä Innovation Oy, 2009).

\section{Biofuels from waste and residues}

Biofuels from wastes (except animal fat based biodiesel) on the contrary have none of the above mentioned disadvantages, as they are not area-intensive and therefore have no influence on LUC, ILUC, biodiversity and food security. The GHG emissions from waste based biofuels are also relatively low. However, this applies only for wastes and residues unless there is no alternative use (e.g. straw for humus balance).

The use of biodiesel from waste fat saves approximately $83 \%$ of GHG emissions (Bundesanstalt für Landwirtschaft und Ernährung, 2010) compared to the fossil reference of $83.8 \mathrm{~g} \mathrm{CO}_{2} \mathrm{eq} \mathrm{MJ}^{-1}$ (2009/29/EC). The available amount of waste and residues naturally cannot cover the demand of biofuels, but because of their strong advantages to fulfil the biofuel requirements according to directive 2009/28/EC their role in the biofuel sector should be intensified. Different technologies for the processing of waste and residues to biofuels are available. Some of them are still in development or in the process of upscaling, others are already mature. Independent of the stage of development the following technologies are currently conceivable: the production of biodiesel from waste fat or oil, the anaerobic fermentation of sugar or starch containing substrates followed by distillation/rectification, the gasification of more or less dry, lignin and cellulose rich substrates followed by fuels synthesis of "Synthetic Natural Gas (SNG)" or "Biomass to Liquid" fuel (BtL) and finally the microbiological production of biogas and its upgrade to biomethane for grid injection. The mentioned technologies are able to convert different kinds of waste and residues. Table 1 shows different types of biomass waste and residue material together with potential biofuel types they could be converted to.

\section{RESULTS OF THE INTERNATIONAL PROJECT REVIEW}

The aim of the international project review was to identify already existing sustainable options of biofuel production concepts and techniques as well as current R\&D projects. The review was web based and considered the sustainability indicators land use and land use change, production of food and fodder, biodiversity and factors of social sustainability. However the results of the latter are not considered in this paper. The results of interest for this study are summarized in Table 2. They are to be understood as a short outlook without any claim of completeness.

The Canadian company "ENERKEM" uses the biogenic fraction of domestic waste and waste wood to produce ethanol and methanol from syngas within a standardized thermochemical

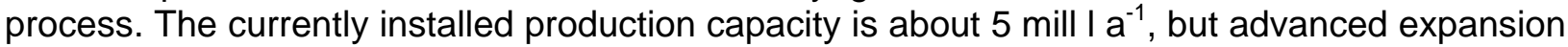
plans have been proposed for two more factories (CA and US) with a planned production

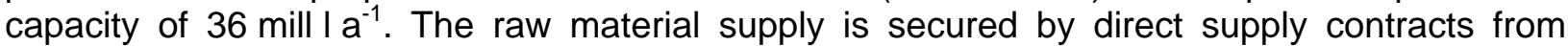
surrounding cities and factories (ENERKEM, 2011). The German "BRV GmbH" uses catering wastes and decayed food for the production of biomethane. The produced biogas is upgraded to biomethane by the use of semi-permeable membranes before injected into the gas grid. The production capacity is $25.000 \mathrm{MWh} \mathrm{a}^{-1}$ with a grid injection power of $300 \mathrm{Nm}^{3} \mathrm{~h}^{-1}$ (Deutsche Energieagentur, 2010). Another approach is the Finnish company ST1 Biofuel Oy, which produces ethanol $(\sim 85 \%)$ with small decentralised modules. These modules use residues and wastes from food processing factories for the production transportable ethanol ( $85 \%)$. The produced Ethanol is dehydrated in a central factory. This concept enables the utilisation of local accruing waste and residues (St1 Biofuels, 2010). An example for sustainable recycling is represented by the approach of the Honduras based "Aquafinca Saint Peter Fish" fish farm. Beside fish oil for food purposes, they produce biodiesel from fish-waste based oil. This biodiesel $\left(6000 \mathrm{I} \mathrm{d}^{-1}\right.$ ) is used for company own cars and generators (Hoff Gomez, 2009). In addition to these already implemented wastes to biofuel approaches, there is a lot of R\&D activity in the field of waste utilisation and technology adaption for biofuel production. In this 
context examples are the "ETAMAX" project of the "Fraunhofer Institute of Interfacial Engineering and Biotechnology (Fraunhofer IGB)", the "bioliq" project of the "Karlsruher Institut of Technology (KIT)" and a project of the US and GB based company "INEOS Bio".

Table 2. International examples of waste to biofuel projects, GHG-reduction refers to the fossil reference according to 2009/28/EC

\begin{tabular}{llllc}
\hline Firmal Project & Land & Feedstock & Biofuel & $\begin{array}{l}\text { GHG- } \\
\text { reduction }\end{array}$ \\
\hline Enerkem & CA & sorted domestic waste, waste wood & $\begin{array}{l}\text { ethanol from } \\
\text { syngas }\end{array}$ & $87 \%^{\star \star}$ \\
\hline $\begin{array}{l}\text { Biogaspartner/ } \\
\text { „BRV“ GmbH }\end{array}$ & DE & catering waste und decayed food & biomethane & $73 \%^{\star \star}$ \\
\hline St1 Biofuels Oy & $\mathrm{FI}$ & food processing residues & ethanol & $80 \%^{*}$ \\
\hline $\begin{array}{l}\text { Aquafinca Saint } \\
\text { Peter Fish }\end{array}$ & $\mathrm{HN}$ & fish oil from fish processing industry & biodiesel & $83 \%^{*}$ \\
\hline Etamax & DE & $\begin{array}{l}\text { wet, lignin low organic waste and } \\
\text { algae biomass }\end{array}$ & biomethane & $73 \%^{\star *}$ \\
\hline Bioliq & DE & straw, hay, waste wood etc. & BtL & $95 \%^{\star *}$ \\
\hline Ineos Bio & US/ GB & waste and residues for gasification & ethanol & $90 \%^{*}$ \\
\hline
\end{tabular}

*manufacturer's data, ** default values (Bundesanstalt für Landwirtschaft und Ernährung, 2010)

The aim of the Project "ETAMAX" is the utilisation of wet organic waste (e.g. from superstores) for the production of biogas, within a high load digestion process and with subsequent biomethane upgrading. To extend the substrate spectrum they conduct research on the production and utilisation of algal biomass within the biogas process. For optimal material utilization the catalyst driven hydrothermal gasification of the resulting fermentation waste is being tested (Amor et al., 2010). It has to be observed, that the production of biofuels from algal biomass is not yet economic. The production cost are approximately $50 € / /$, but algal biomass is highly productive and contains a lot of polysaccharides and lipids which could be used for different kinds of biofuel production (Singh Nigam Murphy 2011). To reduce the costs for alga production it is conceivable to grow them in effluent streams of wastewater treatment plants as already demonstrated by the New Zealand National Institute of Water and Atmospheric Research (NIWA, 2010). Within this process nutrients are removed from the wastewater, whereby a load removal of high nutrient freights into the recipient can be achieved beneficially. It remains the question of how to convert the algal biomass into biofuels. Therefore two main approaches exist which focus on thermochemical conversion of the whole algal biomass, or the biological conversion like anaerobic digestion, as shown in the case of "ETAMAX", fermentation of cell components and others (Nigam Singh, 2011). Within the project „bioliq“, the pyrolysis, gasification and synthesis of different types of dry waste and residues with high lignin and cellulose content is analysed. The concept includes the decentralised flash pyrolysis of the mentioned waste categories and a central gasification and synthesis of biofuel (Hippler Umbach, 2010). Possible feedstock and the potentials are described in more detail in the next part of the study. For the production of Ethanol from organic waste, INEOS Bio focuses on a combination of gasification followed by fermentation of the syngas to Ethanol (patented genetic modified microorganisms), finally followed by distillation and rectification (INEOS Bio, 2010).

\section{WASTE POTENTIALS IN GERMANY}

Within the joint project "BioWaste to liquid: Utilisation of biogenic residues and waste in thermochemical systems for the provision of fuels" the application potential of different biogenic residues for flash pyrolysis was analysed. The project was realised by the "DBFZ Deutsches Biomasseforschungszentrum gemeinnützige $\mathrm{GmbH}$ " and the "Karlsruhe Institute of Technology (KIT)". One of the aims of the study was the identification of hitherto not used feedstock for pyrolysis which is suitable for the thermochemical process and which is available in large amounts (technical feedstock potential). Feedstock exclusion criteria included high water 
content, high ash content, low heating value and its potential of energy densification. On the other hand, it was important that the biomass occurs in an amount that enables utilisation despite competitions of use. Furthermore, biomass fractions that have a low overall potential but which do have local peaks (e.g. flotsam) were analysed with respect to a local utilisation. In the case of woody biomass, only bark and residues of the wood processing industry remain for thermochemical treatment.

Table 3. Technical potential of woody and herbaceous biomass for thermo chemical conversion

\begin{tabular}{lc}
\hline Residue & Technical Potential \\
\hline Woody residues & 4.1 mill t fm \\
Bark & 2.4 mill t fm \\
$\begin{array}{l}\text { Wood processing residues } \\
\text { Herbaceous residues }\end{array}$ & 1.2 mill t fm \\
$\begin{array}{l}\text { Straw and other residues from oil } \\
\text { bearing plants }\end{array}$ & 8.1 mill t fm \\
$\begin{array}{l}\text { Straw and other residues from } \\
\text { cereals and corn }\end{array}$ & \\
\hline
\end{tabular}

On the one hand bark, with 4.1 mill $\mathrm{t}$ fm (fresh matter, technical feedstock potential of the years 2002 - 2010 (Bundesministerium für Ernährung, Landwirtschaft und Verbraucherschutz, 2004 \& 2009), is available in large amounts despite a lot of competitions of use and it is easy to mobilise on the other hand. Waste wood is not applicable to a great extent because of its high pollution potential. In this category only wood processing residues are applicable and provide a potential of 2.4 mill t fm (Statistisches Bundesamt, 2006; Institut für Energetik und Umwelt, 2003). In the case of herbaceous biomass, the sub-categories "straw and agricultural residues" are suitable for pyrolysis and gasification. Straw from oil bearing plants (e.g. rape, sunflower), with 1.2 mill t fm and from cereals or corn, with 8.1 mill t fm (Statistisches Bundesamt Deutschland, 2010) are available in sufficient amounts and have a very low water content of $15 \%$. A summarisation of the different technical potentials of applicable waste categories named above is to be found in Table 3. Leaves of beet and residues from hop cultivation are only applicable for thermochemical treatment with previous drying. They are characterised by a high local potential. Their utilisation for biofuels would be a benefit in opposition to the actual disposal. Wet biomass like liquid manure or organic waste can be used for biogas or biomethane production. In Germany about 3.9 mill t $\mathrm{a}^{-1}$ domestic organic waste accrues. In total, with garden- and park waste, landscape conservation material as well as catering- and food processing waste, this category provides a potential of $30 \mathrm{PJ} / \mathrm{a}$. An optimised separate collection could enhance this potential up to $50 \mathrm{PJ}$ (Kern et al., 2010). The valorisation to biofuels could make a considerable contribution towards the goals of the German National Renewable Energy Action Plan 2010 (NREAP, 2010). The aim of the NREAP 2010 is a 2.5 $10.2 \%$ share of $2^{\text {nd }}$ generation biofuels in general. As already mentioned, there are many other wastes and residues with much higher potentials, like logging remains or agricultural residues which could be volatised to biofuels, so that the 2020 aims of the NREAP 2010, concerning the share of $2^{\text {nd }}$ generation biofuels, could be increased.

\section{BASIC FUNDING APPROACHES FOR BIOFUELS FROM WASTE AND RESIDUES IN THE EC}

Because of their advantages, biofuels from waste and residues can be counted twice in the mandatory biofuel blending quota according to the directive 2009/28/EC. This "double counting" only applies to biofuels from wastes, residues, cellulose based non-food materials and lignocellulose based materials. As a result, these biofuels obtain a price advantage compared to $1^{\text {st }}$ generation biofuels and others. The price advantage from "double counting" results from the difference between the market price for fossil fuels and the market price for biofuel-substitutes, which are not eligible for "double counting". For example, in the case of Fischer-Tropsch-Diesel, the price advantage would be the difference between the market price of fossil Diesel (gas 
station price less VAT) and the market price of the purchased amount of biodiesel (prime costs plus distribution costs plus energy tax) that is needed to fulfil the mandatory blending. Therefore, this price advantage is not static. It depends especially on fluctuations in the prices of oil, natural gas and in prime costs of $1^{\text {st }}$ generation biofuels. Figure 1 shows the average gas station prices in Germany, including distribution costs and energy tax for petrol, diesel and natural gas, less VAT in comparison to primary costs of $1^{\text {st }}$ generation biofuels that cannot be counted twice on the mandatory blending quota (biomethane from whole plant silage (wps), rape based biodiesel and cereal based ethanol). The difference between the two parameters determines the price advantage of biofuels based on waste and residues compared to other biofuels. At current prices, this advantage accounts for $50 \mathrm{Ctl}^{-1}$ concerning biomethane and biodiesel and about $34 \mathrm{Ct} \mathrm{l}^{-1}$ concerning bioethanol. Crucial for "double counting" is the comparison with the primary costs of miscellaneous biofuels represented in Figure 1. Regarding this, biofuels from waste can cause less costs than alternative biofuels, e.g. $1^{\text {st }}$ generation biofuels. The green rhombus in Figure1 illustrates this difference. As already mentioned, the price of double counting capable biofuels is not static and therefore associated with uncertainties (the price difference between established biofuels and the fossil reference is volatile). Considering actual feedstock prices of $1^{\text {st }}$ generation biofuels and fossil fuels, the calculations indicate promising price advantages of double counting capable biofuels in comparison to biofuels from rape or grain. This price advantage could only be diminished by significant reductions in prices of fossil fuels or feedstock of $1^{\text {st }}$ generation biofuels. Additional indirect funding incentives could result from the switch in the biofuel blending quota. In 2015, the blending quota will be replaced by a system based on GHG-emission reductions. This could lead to further indirect funding incentives. The demand for biofuels with a relatively good GHGbalance will rise and be reflected in a direct GHG-balance based price advantage. In this respect, biofuels from waste and residues will be very convenient.

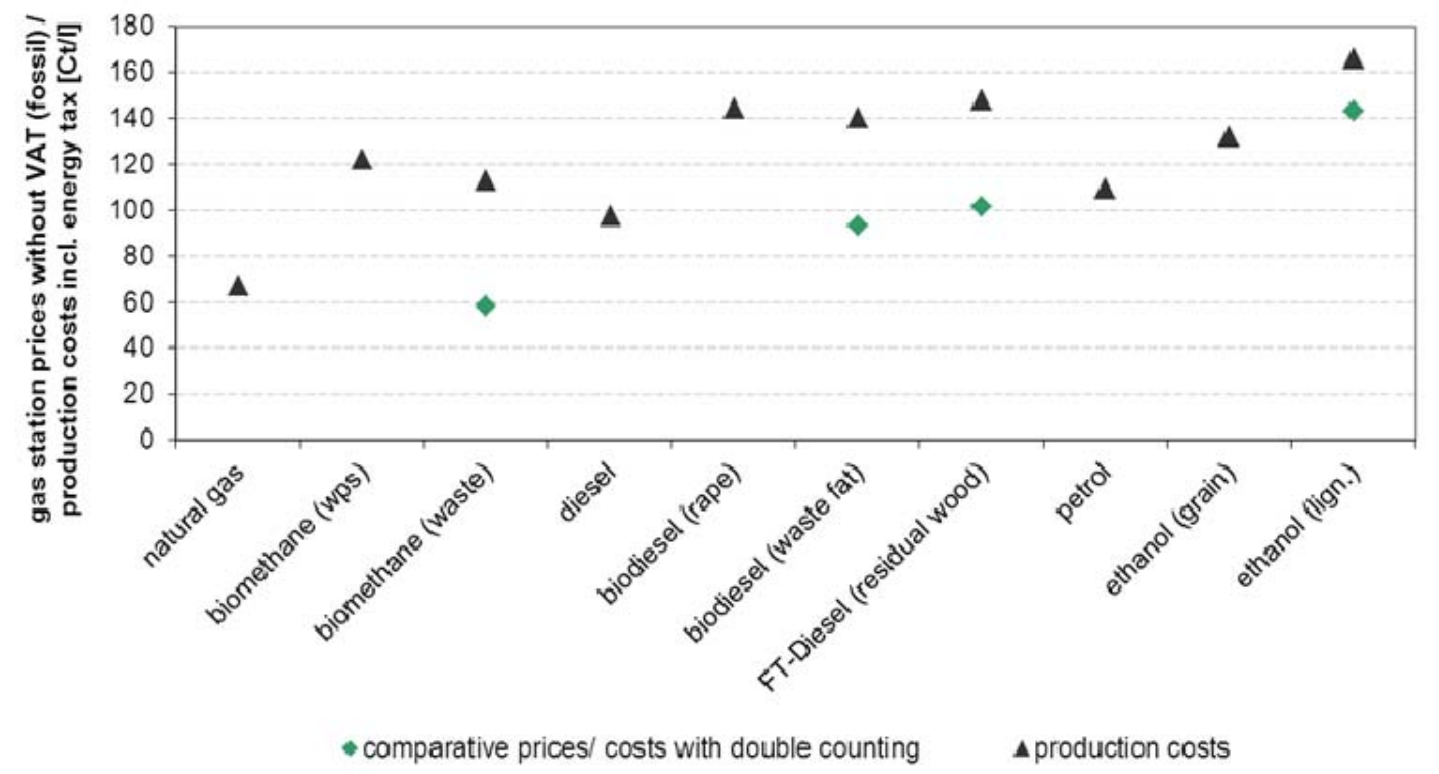

Figure 1. Effects of "double counting" on the profitability of biofuels (DBFZ 2010)

\section{CONCLUSION}

Current biofuels, used to fulfil the mandatory blending quota, are dominated by $1^{\text {st }}$ generation biofuels based on oil and sugar bearing plants. Due to associated land use intensity, GHGemissions from agriculture (e.g. $\mathrm{N}_{2} \mathrm{O}$ ), growing worldwide food insecurity, and pressure on biodiversity caused by intensive monocultures and genetic modified plants as well as different social factors, these biofuels cannot be described as sustainable solution. Existing methods of resolution, like the cultivation on degraded lands do not seem to change this problem, basically because of unknown availability and suitability and the lack of concepts to use these areas. According to the definition of sustainability, only biofuels from waste and residues can fulfil the 
given criteria. This approach further enables the cascade use of biomass (material use before energetic utilisation). Therefore, the identification, quantification and quality analysis of different waste streams is very important. Technologies for biofuel production from wastes and residues reach from transesterification of waste fats over anaerobic fermentation and distillation, biomethane production up to gasification followed by synthesis of biofuels (SNG and BtL). In some cases, techniques still have to be adapted to the feedstock (e.g. gasification) or the feedstock needs to be pre-conditioned (e.g. by treatment with enzymes, torrefaction, ensiling, pyrolysis). Therefore, enhanced research concerning the adaption and development of applicable technologies as well as gathering and separation strategies for wastes and residues is

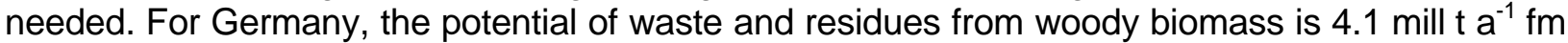
for bark and 2.4 mill $\mathrm{t}^{-1} \mathrm{fm}$ for wood processing residues. Straw from different kinds of plants (oil plants, cereals and corn) constitutes 9.3 mill t $^{-1} \mathrm{fm}$. The actual gathered waste potential could be raised up by intensification of gathering. Special funding opportunities for biofuels from wastes and residues are given in form of "double counting" according to 2009/28/EC and an assumed higher demand because of the switch from an amount based blending quota to a GHG-based quota in 2015.

\section{ACKNOWLEDGEMENTS}

The research projects "Social and behavioural aspects of biofuel production and use" and "BioWaste to liquid: Utilisation of biogenic residues and waste in thermo-chemical systems for the provision of fuels", as basis for this study, were generously supported by the Federal Ministry of the Environment, Nature Conservation and Nuclear Safety (BMU).

\section{REFERENCES}

2009/28/EC Directive of the European Parliament and of the European Council of 23 April 2009 on the promotion of the use of energy from renewable sources and amending and subsequently repealing Directives 2001/77/EC and 2003/30/EC.

Amor J., Andrees I., Bangert M., Hetebrüg A., Krieg S., Rösslein K., Steinmetz B. and Vorbeck C. (2010), Jahresbericht 09/10, Fraunhofer-Institut für Grenzflächen und Bioverfahrenstechnik IGB, Stuttgart

Bai Z.G., Dent D.L., Olsson L., Shaepman A.E. et al., (2008), Global Assessment of Land Degradation and Improvement, Identification by remote sensing, GLADA Report, ISRIC, Wageningen

Balooni K. and Singh K. (2003), Financing of wasteland afforestation in India, Natural Resources Forum, 27, 235-246

Bundesanstalt für Landwirtschaft und Ernährung (BLE) (2010), Leitfaden nachhaltige Biomasseherstellung, BLE, Bonn

Bundesministerium für Ernährung Landwirtschaft und Verbraucherschutz (BMELV) (2004), Die zweite Bundeswaldinventur - BWI², BMELV

Bundesministerium für Ernährung Landwirtschaft und Verbraucherschutz (BMELV), (2009), Holzmarktberichte. Abschlussergebnisse für die Forst- und Holzwirtschaft 2002-2008, BMELV

Campbell E.J., Lobel D.B., Genova R.C. and Field C. (2008), The global potential of bioenergy on abandoned agricultural land, Environmental Science and Technology, 15(42), 5791-5794, (doi:10.1021/es800052w)

Cornelissen S. and Dehue B. (2009), Summary of approaches to accounting for indirect impacts of biofuel production, Ecofys

Cotula L., Vermeulen N.D. and Vermeulen S. (2008), Fuelling Exclusion? The Biofuels boom and poor people`s access to land, IIED, London.

Deutsche Energieagentur (dena) (2010), Biogaspartner: Einspeiseatlas, URL: http://www. biogaspartner.de/index.php?id=10063\& L=gsjykpsmyqme (accessed 04/10/2010)

ENERKEM (2011), URL: http://enerkem.com/en/home.html, (accessed 10/02/2011)

FAOSTAT, URL: http://faostat.fao.org/ (accessed 11/11/2010)

Field C.B., Campbell E.J. and Lobell D.B. (2007), Biomass energy: the scale of the potential resource, Trends in Ecology and Evolution, 23, 65-72

Fischer G., Hyzsnyik E., Prieler S., Sha, M. and van Velth H. (2009), Biofuels and Food Security a study OFID Study prepared by the IIASA, OFID, Wien

Gibbs H.K., Ruesch A.S., Achard F., Clayton M.K., Holmgren P., Ramankutty N. and Foley J.A. (2010), Tropical forests were the primary sources of new agricultural land in the 1980s and 1990s, PNAS, (www.pnas.org/cgi/doi/10.1073/pnas.0910275107)

Hippler H. and Umbach E. (2010), Bioliq - Forschungszentrum Karlsruhe, URL: 
http://iwrwww1.fzk.de/bioliq/index.html, (accessed 10/5/2010)

Hirschfeld J., Weiß J., Preidl M. and Korbun T. (2008), Klimawirkung der Landwirtschaft in Deutschland, Schriftenreihe des IÖW, IÖW, Berlin

Hoff R. and Gomez A. (2009), Honduras Biofuel Annual Report 2009, Global Agriculture Information Network

URL:http://gain.fas.usda.gov/Recent\%20GAIN\%20Publications/General\%20Report_Tegucigalpa Honduras_5-28-2009.pdf

Hoogwijk M.M. (2004), On the global and regional potential of renewable energy sources, PhD Thesis, Utrecht University, Utrecht

INEOS Bio (2010), URL: http://www.ineosbio.com/57-Welcome_to_INEOS_Bio.htm (accessed 4/3/2010)

Institut für Energetik und Umwelt (IE) (2003), Monitoring zur Biomasseverordnung auf Basis des Erneuerbare-Energien-Gesetzes (EEG) aus Umweltsicht, Endbericht, IE GmbH, Leipzig.

Jyväskylä Innovation Oy and MTT Agrifood Research Finland (2009), Energy from field energy crops - a handbook for energy producers, Jyväskylä, URL: www.encrop.net

Kern M., Raussen T., Funda K., Lootsma A. and Hofmann H. (2010), Aufwand und Nutzen einer optimierten Bioabfallverwertung hinsichtlich Energieeffizienz, Klima- und Ressourcenschutz; Umweltbundesamt, Dessau-Roßlau

Meissner M. (2009), Klimaschädliche Landwirtschaft, Positionspapier, WWF, Berlin

National Institute for Water and Atmospheric Research NIWA (2010) Bio-oil from wastewater algae URL: http://www.niwa.co.nz/our-science/freshwater/research-projects/biofuel-from-wastewater-algae (accessed 10/5/2010)

Nigam P.S. and Singh A. (2011) Production of biofuels from renewable resources, Progress in Energy and Combustion Science, 37, 52-68.

NREAP (2010), Nationaler Aktionsplan für erneuerbare Energie gemäß der Richtlinie 2009/28/EG zur Förderung der Nutzung von Energie aus erneuerbaren Quellen, URL: http://www.erneuerbareenergien.de/files/pdfs/allgemein/application/pdf/nationaler_aktionsplan_ee.pdf

Singh A., Nigam P.S. and Murphy J.D. (2011) Mechanism and challenge in commercialisation of algal biofuels, Bioresource Technology, 102, 26-34.

St1 - Biofuels (2010), Waste to ethanol, URL: http://www.st1.eu/index.php?id=2874, (accessed 19/4/2010)

Statistisches Bundesamt (2006), Abfallentsorgung 2006 - Input ausgewählter Abfälle in Abfallentsorgungsanlagen nach Bundesländern, Statistisches Bundesamt

Statistisches Bundesamt Deutschland (DESTATIS) (2010), Spezielle Bodennutzung und Ernte Ackerland nach Hauptfruchtgruppen und Fruchtarten, URL:http://www.destatis.de/ (accessed 10/12/2010)

UNEP (United Nations Environmental Programme) (2007), Global Environment Outlook (Geo-4); Nairobi, (http://unep.org/geo/geo4/media/)

Vohland K., Doyle U. and Cramer W. (2008), Der Einfluss von Klimaveränderungen auf die Biodiversität, Aus Politik und Zeitgeschichte, 3, 31-38.

WBGU (2009), Zukunftsfähige Bioenergie und nachhaltige Landnutzung; WBGU, Berlin, Welt im Wandel, ISBN: 978-3-936191-21-9

Wiegmann K., Hennenberg K.J.and Fritsche U.R. (2008), Degraded Land and Sustainable Bioenergy Feedstock Production - Issue Paper -, Öko Institut, Darmstadt.

Zeddies J. (2006), Rohstoffverfügbarkeit für die Produktion von Biokraftstoffen in Deutschland und in der EU-25, Hohenheim University, Hohenheim. 